\title{
Nutritional Value of Putak: Apparent Metabolisable Energy, and Growth Performance
}

\author{
Catootjie L. Nalle (Corresponding Author) \\ Feed Technology Study Program, Animal Husbandry Department, Polytechnic of Agriculture \\ Kupang, Prof. Herman Yohannes St. Lasiana, Kupang, NTT - Indonesia \\ Phone: +62 380 881600; fax +62 380 881601. Email: catootjienalle@gmail.com \\ Marlin R.K.Yowi \\ Animal Health Study Program, Animal Husbandry Department, Polytechnic of Agriculture \\ Kupang, Prof. Herman Yohannes St. Lasiana, Kupang, NTT - Indonesia \\ Phone: +62 380 881600; fax +62 380881601 Email: marlin_ntt@yahoo.co.id \\ Defrys R. Tulle \\ Animal Production Study Program, Animal Husbandry Department, Polytechnic of Agriculture \\ Kupang, Prof. Herman Yohannes St. Lasiana, Kupang, NTT - Indonesia \\ Phone: +62 380 881600; fax +62 380881601 Email: defrys@gmail.com
}

(Received: Mar 12, 2017; Reviewed: Mar 17, 2017; Accepted: May 27, 2017)

DOI: http://dx.doi.org/10.20956/ijas.v5i1.1170

\begin{abstract}
Two experiments were conducted to evaluate nutritional value of putak for broilers. Experiment 1. The apparent metabolisable energy of raw and fermented putak were determined. The experimental design used was completely randomized design with three treatments and four replicates. Total of 64 broilers were randomly distributed to 16 pens. A maize-soybean meal basal diet was formulated and three assay diets were then developed by substituting putak (raw, and fermented, $250 \mathrm{~g} \mathrm{~kg}^{-1}, \mathrm{w} / \mathrm{w}$ ), and maize $\left(500 \mathrm{~g} \mathrm{~kg}^{-1}, \mathrm{w} / \mathrm{w}\right)$ of the basal diet. Even though the AME and AMEn values of fermented putak were comparable to that of raw putak and maize, but it was slightly higher than that of raw putak. Experiment 2. Using the AME value of raw putak obtained in Experiment 1, five treatment diets containing 0 to $200 \mathrm{~g} \mathrm{~kg}^{-1}$ putak were formulated. The body weight gain of broilers fed $150-200 \mathrm{~g} \mathrm{~kg}^{-1-1}$ putak was higher to that of control diet, but it was similar to those fed $50-100 \mathrm{~g} \mathrm{~kg}^{-1}$ putak. No differences were found in FCR and mortality rate. Feed intake of broilers fed diets containing putak was higher than that of control diet. In conclusion, the AME and AMEn values of putak, fermented putak, and maize were comparable. Putak can be included in broiler diets up to $200 \mathrm{~g} \mathrm{~kg}^{-1}$ without detrimental effects.
\end{abstract}

Keywords: putak; broiler; AME, AMEn; production performance 


\section{Introduction}

Poultry feed industry is still mainly depending on maize as the main energy source in the diets formulated for poultry. Beside its high energy content, the nutrient digestibility of maize is high, and it is palatable. The amino acid content of maize depends on its variety. Shresta and Tripathi (2014) reported that quality protein maize is richer in lysine and tryptophan compared to normal maize. However, the problem faced by poultry feed industry is the fluctuative availability of maize due to the season, which can lead to unstable price, and even the price tends to increase every year. Because of that, it is necessary to evaluate the alternative energy feed ingredients to partly substitute the proportion of maize in poultry ration.

The availability of energy source feed ingredients as maize replacement in each country is different, for example Indonesia has rice bran, and putak. Rice bran has been widely used in poultry ration but the inclusion level of this material is limited in broiler ration due to its high fibre content and phytic acid. Putak is the sago obtained from the pith of gebang tree (Corypha gebanga) which is found abundantly in NTT province in Indonesia. Directorate General of Animal Husbandry in Indonesia (2008) reported that approximately 4,876 ha pasture in Timor Island, in NTT province, Indonesia planted by gebang tree. Nulik et al. (1988 cited by Hilakore, 2008) reported that from one gebang tree (height $15 \mathrm{~m}$ ) produced 415 kg (60\% DM). Palma Plant Research Centre (2015) reported that $663 \mathrm{~kg}$ putak can be produced from a tree. Putak that has been peeled was sold in differnt size and price per piece $(\operatorname{Rp} 7,500-30,000)$.

Putak has been used as ruminant diet for long time in NTT province. The utilisation of putak in poultry diet is limited due to its high fibre content. The fibre content of putak was reported about $124 \mathrm{~g} \mathrm{~kg}^{-1}$ (Ginting, 2000 cited by Hilakore, 2008).

The effort to improve the nutritional value of putak is still limited. In addition, published data regarding the effect of putak meal as maize replacement on the production performance are very scanty. The present study, therefore evaluated the nutritional value of putak for broiler chickens.

\section{Materials and Method}

\subsection{Ingredients}

Putak fermented with Aspergillus niger ( $3 \mathrm{~g} \mathrm{~kg}^{-1}$ ), unfermented putak and maize used in the experimental diets were obtained from commercial suppliers. Putak, in stem form, was peeled and ground using special grinder prior to use. The fermentation of putak was carried out by mixing $1000 \mathrm{~g}$ putak with water (200 ml), then spread Aspergillus niger (powder, $3 \mathrm{~g} / \mathrm{kg}$ ) into the top of putak meal. The mixture was then packed into plastic bag, and kept for 14 days in a room at ambient temperature. On day 21, the fermented putak was unpacked, spreaded equally into a tarpaulin, and then sun-dried for 2 days. Sun-dried fermented putak was then ground $(0.5 \mathrm{~mm})$ for laboratory analysis, and used for AME assay.

\subsection{Metabolisable energy}

A maize-soybean meal basal diet was formulated and three assay diets were then developed by substituting putak, and fer- 
mented putak (250 $\mathrm{g} \mathrm{kg}^{-1}$ (w/w), and maize (250 $\mathrm{g} \mathrm{kg}^{-1}(\mathrm{w} / \mathrm{w})$ of the basal diet (Table 1 and Table 2). Day-old male and female broilers (CP 707) were raised in floor pens and fed a commercial broiler starter diet (230 $\mathrm{g} \mathrm{kg}^{-1}$ crude protein) till day 21. Feed and water were available at all times. On day 21, 64 birds of uniform body weight were selected and randomly assigned to 16 cages (4 birds per cage). The birds were offered a commercial broiler finisher diet $\left(180 \mathrm{~g} \mathrm{~kg}^{-1}\right.$ crude protein) until the introduction of assay diets on day 28 . On day 28 , four replicate cages were randomly assigned to each assay diet.

Table 1. Treatment diets for metabolisable energy determination. Experiment 1

\begin{tabular}{ll}
\hline Diets & \multicolumn{1}{c}{ Treatments } \\
\hline A & Basal diet (maize-soybean meal) \\
B & Basal diet (maize-soybean meal) $+25 \%$ putak \\
C & Basal diet (maize-soybean meal) $+25 \%$ fermented putak \\
D & Basal diet (maize-soybean meal) $+50 \%$ maize \\
\hline
\end{tabular}

Table 2. Basal diet composition (g/kg air dry basis)

\begin{tabular}{lc}
\hline Ingredient & \\
\hline Maize & 594.6 \\
Soybean meal & 351.8 \\
Vegetable oil & 17.8 \\
Dicalcium phosphate & 21.7 \\
Limestone & 7.8 \\
Salt & 2.0 \\
Sodium bicarbonate & 2.3 \\
Trace mineral-vitamin premix & 3.0 \\
\hline
\end{tabular}

Sanmix, PT Sanbe Farma, per kg provided:Vit A (1250000IU), Vit D3 (250000IU), Vit E (750 IU), Vit K (200 mg), Vit B1 (150 $\mathrm{mg}$ ), Vit B2 (500 mg), Vit B6 (500 mg), Vit B12 (1012 mcg), Vit C (3000 mg), Ca-dpantothenate $(500 \mathrm{mg})$, Niacin $(3500 \mathrm{mg})$; methonine $(3500 \mathrm{mg})$, Lysine $(3500 \mathrm{mg})$, Manganese (10000 mg), Iron (2500 mg);
Iodin (20 mg), Zn (10000 mg), Cobalt (20 mg), Copper (300 mg), Antioxidant (1000 $\mathrm{mg})$.

Table 3. The chemical composition of putak, fermented putak and maize $(\mathrm{g} / \mathrm{kg} \mathrm{DM})^{*}$ used in the experimental diet- Experiment 1

\begin{tabular}{lccc}
\hline \multicolumn{1}{c}{ Nutrient } & Putak & Fermented Putak & Maize \\
\hline Dry matter & 876.5 & 883.9 & 883.1 \\
Ash & 50.4 & 50.3 & 17.2 \\
Crude Protein & 36.6 & 45.8 & 91.7 \\
Crude Fibre & 99.5 & 75.2 & 22.9 \\
Ether Extract & 3.2 & 0.6 & 14.4 \\
NFE & 736.8 & 712.0 & 736.9 \\
Ca & 18.0 & 17.3 & 11.5 \\
P & 4.2 & 4.5 & 5.5 \\
ADF & 81.4 & 154.4 & 165.6 \\
NDF & 267.5 & 303.8 & 365.3 \\
\hline
\end{tabular}

Table 4. The amino acid composition of putak, fermented putak and maize $(\mathrm{g} / \mathrm{kg} \mathrm{DM})^{*}$ used in the experimental diet- Experiment 1

\begin{tabular}{lccc}
\hline Amino acids & Putak & Fermented Putak & Maize \\
\hline Asam Aspartat & 1.9 & 5.8 & 5.0 \\
Asam Glutamat & 4.8 & 13.6 & 1.2 \\
Serin & 0.6 & 1.5 & 1.7 \\
Glysin & 1.7 & 5.1 & 1.3 \\
Histidin & 0.9 & 2.9 & 0.9 \\
Arginin & 0.8 & 1.8 & 1.6 \\
Threonin & 0.9 & 1.8 & 1.1 \\
Alanin & 1.9 & 3.6 & 3.2 \\
Prolin & 0.4 & 1.4 & 3.9 \\
Tyrosin & 0.3 & 1.2 & 1.2 \\
Valin & 1.2 & 3.8 & 2.1 \\
Metionin & 0.7 & 2.9 & 0.8 \\
Sistin & 0.2 & 1.2 & 0.7 \\
Iso-leusin & 0.8 & 2.3 & 1.2 \\
Leusin & 2.2 & 6.6 & 0.6 \\
Phenil Alanin & 0.7 & 1.7 & 1.8 \\
Lysin & 1.2 & 5.2 & 1.0 \\
\hline * Analised by Bogor Agricultural University &
\end{tabular}

*Analised by Bogor Agricultural University

The AME was determined using the classical total excreta collection method. The diets, in mash form, were fed to birds from day 28. Feed intake and excreta output were measured quantitatively per cage from day 32 for four consecutive days. The excreta from each cage were pooled, mixed, subsampled and oven-dried. The dried excreta samples, together with samples of the diets, were subsequently ground to pass through 
$0.5-\mathrm{mm}$ sieve and stored in airtight plastic containers for analysis of dry matter, gross energy and nitrogen.

\section{Chemical Analysis}

The dry matter (DM) content was determined in a convection oven at $105^{\circ} \mathrm{C}(\mathrm{AOAC}, 2005$; method no. 930.15). Gross energy was determined using an adiabatic oxygen calorimeter (Gallenkamp Autobomb, London, UK) standardised with benzoic acid. Nitrogen content was determined using Kjeldahl method.

\section{Calculations}

The AME values of the test diets were calculated using the following formulas:

(Equation 1.) $\mathrm{AME}_{\text {diet }}(\mathrm{MJ} / \mathrm{kg})=($ feed intake $\mathrm{x}$

$$
\begin{gathered}
\left(\mathrm{GE}_{\text {diet }}\right)-\left(\text { excreta output } x \mathrm{GE}_{\text {excreta }}\right) \\
\text { Total feed intake }
\end{gathered}
$$

(Equation 2.) $\mathrm{AME}_{\text {raw and processed putak }}(\mathrm{MJ} / \mathrm{kg})=$ AME of raw and processed putak diet - (AME basal diet $\mathrm{x} 0.75$ )

Correction for zero nitrogen retention was made using a factor of $36.54 \mathrm{~kJ}$ per gram nitrogen retained in the body (Hill and Anderson, 1958).

\section{Experiment 2-Feeding trial}

Birds and housing: Total of 200 day-old broilers (mix male and female, CP 707) obtained from local commercial hatchery were assigned on the basis of body weight to the 20 floor pens (10 birds/pen).

Diets: The chemical composition, and amino acid content of putak used for assay diet formulation were presented in Table 2 and
Table 3. Iso energetic and iso nitrogenous diets containing 0 to $200 \mathrm{~g} \mathrm{~kg}^{-1}$ putak were formulated (Table 5). Each of the three dietary treatments in mash form was randomly assigned to four pens containing 10 chicks each, and the diets were fed from day 1 to 21 .

Measurements: Body weights and feed intake were recorded at day 21 during the experiment. The weight gain and feed intake data were used to calculate feed per gain per treatment group. Feed per gain values were corrected for the body weights of birds that died during the experiment.

Statistical analysis: The pens means were used to derive performance data. The data of AME, AMEn, and performance was analyzed by one-way analysis of variance (ANOVA) using the General Linear Model procedure of SAS (1997). Differences were considered to be significant at $\mathrm{P}<0.05)$ and significant differences between means were separated by the Fisher's Least Significant Difference Test (LSD).

\section{Results and Discussion}

\subsection{Experiment 1: AME determination}

The apparent metabolisable energy value of putak, fermented putak, and maize was summarized in Table 6. The AME and AMEn values of putak, fermented putak and maize were found to be comparable ( $P$ $>0.05)$. In general, the AME and AMEn values of fermented putak were found to be higher than the AME and AMEn values of putak, but they were still lower than that of maize. The AME and AMEn values of 
Table 5. Ingredient composition, and calculated analysis of treatment diets. Experiment 2.

\begin{tabular}{lccccc}
\hline \multirow{2}{*}{ Feed ingredient } & \multicolumn{5}{c}{ Putak Level $\left(\mathbf{g ~ k g}^{-1}\right)$} \\
\cline { 2 - 5 } & $\mathbf{0}$ & $\mathbf{5 0}$ & $\mathbf{1 0 0}$ & $\mathbf{1 5 0}$ & $\mathbf{2 0 0}$ \\
\hline Corn-8.5\% CP & 534.9 & 491.5 & 444.8 & 376.1 & 325.0 \\
Putak & - & 50.0 & 100.0 & 150.0 & 200.0 \\
Soybean meal, 44\% CP & 297.6 & 287.1 & 283.0 & 294.5 & 289.0 \\
Meat and bone meal & 50.0 & 57.5 & 61.0 & 60.0 & 62.5 \\
Fish meal & 50.0 & 52.5 & 52.0 & 55.0 & 55.0 \\
Vegetable oil & 44.5 & 44.0 & 45.0 & 52.5 & 56.0 \\
DL-Methionine 99\% & 2.0 & 1.5 & 1.2 & 0.6 & 0.6 \\
L- Lysine & 0.1 & - & - & - & 0.04 \\
Limestone & 9.0 & 0.50 & 0.20 & - & \\
Dicalcium phosphat & 6.0 & 5.0 & 5.0 & 5.0 & 5.0 \\
Salt & 2.5 & 2.5 & 2.5 & 2.5 & 2.5 \\
Sodium bicarbonate & 0.4 & 0.4 & 0.5 & 0.8 & 1.0 \\
Vit-Min Premix ${ }^{1)}$ & 3.0 & 3.0 & 3.0 & 3.0 & 3.0 \\
\hline Total & $\mathbf{1 0 0 0}$ & $\mathbf{1 0 0 0}$ & $\mathbf{1 0 0 0}$ & $\mathbf{1 0 0 0}$ & $\mathbf{1 0 0 0}$ \\
\hline Calculated analysis ${ }^{2)}$ & & & & & \\
\hline Metabolisanle Energy (Kcal/kg) & 12.98 & 12.99 & 12.99 & 12.97 & 12.97 \\
Crude Protein (g/ kg) & 224 & 224 & 223 & 223 & 221 \\
Lysine (g/ kg) & 12.5 & 12.5 & 12.5 & 12.7 & 12.9 \\
Met + Cys (g/kg) & 9.8 & 9.8 & 9.9 & 9.6 & 9.9 \\
Ca (g/kg) & 10.3 & 10.1 & 10.1 & 10.2 & 11.3 \\
Av P (g/kg) & 4.6 & 4.5 & 4.5 & 4.5 & 4.7 \\
\hline
\end{tabular}

*) Each kg of Sanmix: Vitamin A 1.250.000 IU, vitamin D3 250.000 IU, Vitamin E 750 IU, vitamin K 200 $\mathrm{mg}$, vitamin B1 $150 \mathrm{mg}$, vitamin B2 $500 \mathrm{mg}$, vitamin B6 $500 \mathrm{mg}$, vitamin B12 $1200 \mathrm{mg}$, vitamin C 3000 $\mathrm{mg}$, Ca-d-pantothenate $500 \mathrm{mg}$, Niacin $3500 \mathrm{mg}$, Methionine $3500 \mathrm{mg}$, lysine $3500 \mathrm{mg}$, manganese 10.000 $\mathrm{mg}$, iron $2500 \mathrm{mg}$, Iodine $20 \mathrm{mg}$, Zinc $10.000 \mathrm{mg}$, Cobalt $20 \mathrm{mg}$, Copper $300 \mathrm{mg}$ da, Antioxidant $1000 \mathrm{mg}$.

fermented putak were 12.52 and $11.72 \mathrm{MJ} /$ $\mathrm{kg}$ DM, respectively. The AME and AMEn values of putak were 11.62 and $10.67 \mathrm{MJ} / \mathrm{kg}$ DM, respectively.

The slight improvement of apparent metabolisable energy in putak after fermenting with Aspergillus niger was probably due to the decrease of crude fibre (Table 3). The increase of ADF and NDF of fermented putak shown in Table 2 was unexpected result. The decrease in the fibre content will increase the digestibility and absorption of nutrients. It was reported by Kosseva (2011 cited by Lawal et al., 2013) that Aspergillus niger has the potential of splitting the $\beta-1,4$ linkage in the hemicellulolytic xyloglucans in the gut contents, thereby reducing gut viscosity and improving nutrient absorption.

Table 6. $A M E$ and $A M E n$ values $(\mathrm{MJ} / \mathrm{kg} \mathrm{DM} \pm \mathrm{SD})$ of putak, fermented putak, and maize (as a reference) ${ }^{1}$. Experiment 1.

\begin{tabular}{lcccc}
\hline & Putak & $\begin{array}{c}\text { Fermented } \\
\text { Putak }\end{array}$ & Maize & $\begin{array}{c}\text { P- } \\
\text { value }\end{array}$ \\
\hline AME & $11.62 \pm 0.85$ & $12.52 \pm 0.35$ & $13.15 \pm 0.21$ & 0.010 \\
AMEn & $10.67 \pm 0.76$ & $11.72 \pm 0.32$ & $12.21 \pm 0.18$ & 0.226 \\
\hline
\end{tabular}

${ }^{1}$ Each value is the average of 4 replicates (4 birds/replicate)

Data presented in Table 6 also indicated that the similarity in the AME and AMEn values of raw and fermented putak, and maize proves that putak and fermented putak are potentially used as maize replacement in poultry diets. Fermentation of putak with 
Aspergillus niger resulted in beneficial effects in the nutritional value such as improve the crude protein content, reduce crude fibre, increase all amino acids content.

\subsection{Experiment 2: Feeding trial}

Production performance data during 21 day experiment was summarized in Table 5. In general, the inclusion level of putak significantly $(\mathrm{P}<0.01$ to $\mathrm{P}<0.05)$ affected the body weight gain (BWG) and feed intake of broilers, but it did not affect $(\mathrm{P}>0.05)$ feed per gain and mortality.

Group of birds fed 50 to $100 \mathrm{~g} / \mathrm{kg}$ putak had similar $(\mathrm{P}>0.05)$ BWG with those fed control diets $(0.00 \mathrm{~g} / \mathrm{kg}$ putak $)$ and those given $150-200 \mathrm{~g} / \mathrm{kg}$ putak. The BWG of broilers given diets containing 50 to 200 $\mathrm{g} / \mathrm{kg}$ putak was higher than those fed control diets. The improvement in BWG of birds fed diet containing putak was probably due to the improvement in feed intake (Table 7).

Table 7. Growth performance of broilers starter (0-21 d) fed diets containing different level of putak.

\begin{tabular}{|c|c|c|c|c|}
\hline $\begin{array}{l}\text { Putak level } \\
\text { (g/kg) }\end{array}$ & $\begin{array}{c}\text { BWG } \\
\text { (g/bird) }\end{array}$ & $\begin{array}{c}\text { FI } \\
\text { (g/bird) }\end{array}$ & $\begin{array}{l}\text { Feed per } \\
\text { gain }(g / g)\end{array}$ & $\begin{array}{c}\text { Mortality } \\
(\%)\end{array}$ \\
\hline 0 & $438^{b}$ & $968^{b}$ & 2.151 & 0.05 \\
\hline 50 & $476^{\mathrm{ab}}$ & $1058^{\mathrm{a}}$ & 2.179 & 0.02 \\
\hline 100 & $473^{\mathrm{ab}}$ & $1084^{\mathrm{a}}$ & 2.181 & 0.00 \\
\hline 150 & $499^{\mathrm{a}}$ & $1098^{a}$ & 2.097 & 0.00 \\
\hline 200 & $497^{\mathrm{a}}$ & $1090^{\mathrm{a}}$ & 2.094 & 0.00 \\
\hline Pooled SEM & 14.9 & 54.0 & 0.100 & 0.0001 \\
\hline $\begin{array}{c}\text { Probability, } \mathrm{P}> \\
\text { putak level }\end{array}$ & $*$ & $* *$ & NS & NS \\
\hline \multicolumn{5}{|c|}{$\begin{array}{l}\text { a,b Means of column with the superscripts significant defferenc } \\
\text { e }(\mathrm{P}<0.05), * \text { : Significant }(\mathrm{P}<0.05) ; * \text { : significant }(\mathrm{P}<0.01) \\
\text {; NS: Not significant }(\mathrm{P}>0.05) \\
{ }^{1} \text { Each value is the average of } 4 \text { replicat } \\
\text { es }(10 \text { birds/replicate })\end{array}$} \\
\hline
\end{tabular}

Feed intake of birds fed diets containing 50 to $200 \mathrm{~g} \mathrm{~kg}^{-1}$ was higher than those given control diets. No differences $(\mathrm{P}>0.05)$ were found in feed per gain and mortality rate in all treatment diets. In a review conducted by Ruurd et al. (1999) and Ferket and Gernat (2006), it was explained that there are two main factors affecting feed intake was which are dietary and managerial factors. Dietary factors, dietary nutrient composition, feed formulation, feedstuff inclusion levels, feed pellet quality, antibiotics, flavours, feed processing, and all influence feed intake. Managerial factors, including availability of feed and water to the birds, environmental management, stocking density and health status. Thus the result of the present study indicated that the improvement in feed intake was probably due to dietary factors, especially feedstuff inclusion levels which related to palatability. Higher palability in treatment diets containing putak was probably due to the taste of the feed. The taste of putak is sweet because it contains high carbohydrates. As it is shown in putak contains high nitrogen free exctract (NFE). In NTT province, a few people who live in the village eat putak as rice and maize replacement, especially in the dry season. People like to eat putak because the taste of putak is sweet.

\section{Conclusion}

It was evident from the present study that putak was potential to be used as maize replacement in broiler diets due to its high energy content. The AME, and AMEn values of putak, fermented putak, and maize were similar. Feeding birds with putak in maizesoy basal diets had beneficial effect on weight gain, and feed intake during 21 day feeding trial. Feed per gain and mortality of birds, however, were not affected by dietary treatments during the entire feeding period. 
Thus, the present results indicated that when the diets were balanced to meet nutrient requirements for broilers, the inclusion of putak at $200 \mathrm{~g} / \mathrm{kg}$ as maize replacement could profitably support good production performance of starter broilers housed in floor pens.

\section{Acknowledgement}

Directorate General of Higher Education that has provided funding for this research.

\section{References}

AOAC International, (2005). Official Methods of Analysis of AOAC International. $18^{\text {th }}$ Edition. Gaithersburg, MD.

Choct, M, (1997). Feed enzymes: current and future applications. Proceedings of the 11th Alltech Asia-Pacific Lecture Tour, Melbourne, Australia, pp. 73-81.

H. K. Dei, S. P. Rose, A. M. Mackenzie, R. Amarowicz, (2008). Growth Performance of Broiler Chickens Fed Diets Containing Shea Nut (Vitellaria paradoxa, Gaertn.) Meal Fermented with Aspergillus niger. Poultry Science, 87 (9): 1773-1778. doi: 10.3382/ ps.2008-00055

Direktorat Jenderal Peternakan, (2008). Statistik Peternakan. Jakarta: Dirjen Bina Produksi Peternakan, Departemen Pertanian RI

Ferket, P.R., and A.G. Gernat, (2006).

Factors that affect feed intake of meet birds: a review. International Journal of Poultry Science, 5(10):905-911.
Hilakore, M.A., (2008). Peningkatan kualitas nutritive putak melalui campuran Trichoderma reesei dan Aspergillus niger sebagai pakan ruminansia. Disertasi. Institut Pertanian Bogor.

Hill, F. W., and D. L.,Anderson, (1958). Comparison of metabolisable energy and productive energy determinations with growing chicks. J.Nut, 64, 587603.

Lawal, T.E., S.G. Ademola, A. Owoseni, O.E.Atobatele, and L.O. Orlye, (2013). Use of Aspergillus niger for improving the feeding value of rice offal. African Jounal of Biotechnology, 12(20):30833087.

Palma Plant Research Centre, (2015). Potency of gebang in East Nusa Tenggara Province. Research and development Centres, Agriculture Ministry. Downloaded on March $9^{\text {th }} 2017$ from http:// balitka.litbang.pertanian.go.id/?p=187

Ruurd, T.Z., C.M. Nyachoti, T.A. Scott, D.L. Whittington, H.W. Gonyou, J.F. Patience, (1999). Factors that influence voluntary feed intake. Annual Research Report, page 14-16.

SAS Institute, (1997). SAS/STAT® User's Guide: Statistics. Version 6.12. SAS Institute Inc. Cary, NC, USA.

Shrestha, J. and M.P. Tripati. (2014). Grain yield stability of quality protein maize genotypes across diverse environments of terai and mid hills in Nepal. International Journal of Agriculture System, 2(2): 113-118. 